\section{THE BOROCAINES:}

\section{A NEW OLASS OF LOCAL ANAESTHETICS.}

A. J. COPELAND, M.A., M.B., D.P.H., B.Sc. ERIMEST HART MEMORIAL SCHOLAR OY THE BRITISH MEDICAL ASSOCIATIOAT; AND

H. E. F. NOTTON, B.Sc., A.R.C.S.

(From the Laboratories of Pharmacology and Chemistry, Cambridge.)

Trx object of this investigation was to determine the factors concerned in surface anaesthesia, with a view to finding a local anaesthetic equal in efficiency to cocaine hydrochloride but without its poisonous properties.

The least toxic of the available anaesthetics is ethocaine hydrochloride; this substance, applied directly to sensory nerve fibres, has an effect equal to that of cocaine hydrochloride, but it does not give very satisfactory anaesthesia when injected subcutaneously without adrenaline, and it has little value as a surface anaesthetic either for the eye, nose, or urethra : thus, for the eye it possesses approximately only one-twentieth the efficiency of cocaine hydrochloride. So that the essential information required was why ethocaine lost its virtues when applied to a surface.

\section{Experimental Observations.}

It has been shown"13 that ethocaine hydrochloride (" novocain") has a strong affinity for sensory nerve fibres, but has very little action on sensory nerve fibrils in the eye. But corneal tissue, while containing a close plexus of the finest non-medullated nerve fibrils, has neither blood vessels nor lymphatics, and investigations were first made to determine whether this factor influenced the action.

When ethocaine hydrochloride is dissolved in rabhit or horse serum or in a solution of egg-white, its power of anaesthetizing the rabbit's cornea is increased twenty times, and becomes equal to that of cocaine hydrochloride. Physical adsorption cannot account for this, since neither gum acacia, pure crystalline, egg-albumen, cholesterin, glutathione, and the like augment the degree of anaesthesia. If the proteins are removed by boiling or by dialysis it can be shown by a process of exclusion that the enhanced effect is due to alkali present, and this "serum effect" can be simulated by adding to the solution of ethocaine hydrochloride an equivalent amount of sodium bicarbonate. Alkalis have long heen known to increase the efficiency of cocaine hydrochloride as a surface anaesthetic. ${ }^{12}$ Gros $^{6}$ found that alkali increased the potency of the hydrochlorides of cocaine, ethocaine, alypine, and stovaine on frog's motor fibres, and his findings were confirmed by Sollmann, ${ }^{\circ}$ who extended the principle to include frog's sensory fibres and skin and rabbit's cornea. This increase of efficiency, according to Sollmann, was not observed in intracutaneous injection anaesthesia.

The fact of fundamental importance emerging from observations such as the above, which have been extended by Regnier, ${ }^{15}{ }^{16}$ is that the surface anassthetic effect of cocaine and its analogues is not constant, but can be varied by using different salts of the alkaloid and by adding certain inactive salts to the aqueous solutions used; it is in this that the solution to the problem presented is to be sought. Attention is thus clearly directed to the nature of the components of aqueous solutions of the salts of cocaine and other bases.

When a salt of cocaine formed with a powerful acid (such as hydrochloric acid) is dissolved in dilute solution in water, a considerable proportion of the salt undergoes electrolytic dissociation-that is to say, it dissociates into the electropositive ion of the base and the electro-negative ion of the acid; a portion of the salt doubtless remains in solution as the salt itself. When a salt of cocaine with a very feeble acid, such as acetic acid, is dissolved in water, a large proportion undergoes hydrolytic dissociation-that is to say, it dissociates into the base itself and the acid; provided the acid is sufficiently feeble, practically the whole of the salt may thus undergo hydrolytic dissociation. Under the various conditions thus indicated, the aqueous solution contains as potentially active components the basic cocaine ion, cocaine base itself, and cocaine hydrochloride itself the proportions in which these three components are present in the solution can be varied by using different salts and by adding different physiologically inactive salts to the solution. Since no reason exists for supposing that the three forms of cocaine which may be present in the solution are of identical physiological activity, it would be anticipated that the varying surface anaesthetic action of different cocaine salts in aqueous solution should arise from nonidentity in effect of those three forms. In order to test the accuracy of this surmise the series of observations recorded in Table I was made. We desire to thank Miss C. Lascelles (Laboratory of Biochemistry, Cambridge) for determining the $p \mathrm{H}$ values of the stock solutions.

It will be seen that cocaine hydrochloride solution to which sodium bicarbonate has been added is far more efficient as a local anaesthetic than solutions of other salts of equivalent concentration in base. The $p H$ values of the original stock solutions are given, and it will be seen that the solutions with the higher $p H$ values exert the greater surface anaesthetic action; this result is in accordance with the observations made by Regnier. Now, the solutions of higher $p H$ value are those in which the hydrolytic dissociation predominates, to the more or less complete suppression of electrolytic dissociation and of undissociated salt. The free or hydrolytically dissociated cocaine is thus more powerfully anaesthetic than the electrolytically dissociated base - namely, the electropositive cocaine ion. It is unnecessary now to discuss the significance of the $p H$ values for the other salts given, and it is not suggested that they have quantitative value.

The indication thus obtained that the electrolytically dissociated basic ion and the hydrolytically dissociated base exert very different surface anaesthetic actions can be readily interpreted. The electrolytically dissociated salt would be expected to be absorbed into the circulation more rapidly than the hydrolytically dissociated base; the latter, being absorbed more slowly, should have more opportunity for exhibiting its surface anaesthetic properties.

TABLE I.-Anaesthetic Efficiency of Salts of Cocaine on Rabbit's Cornea.

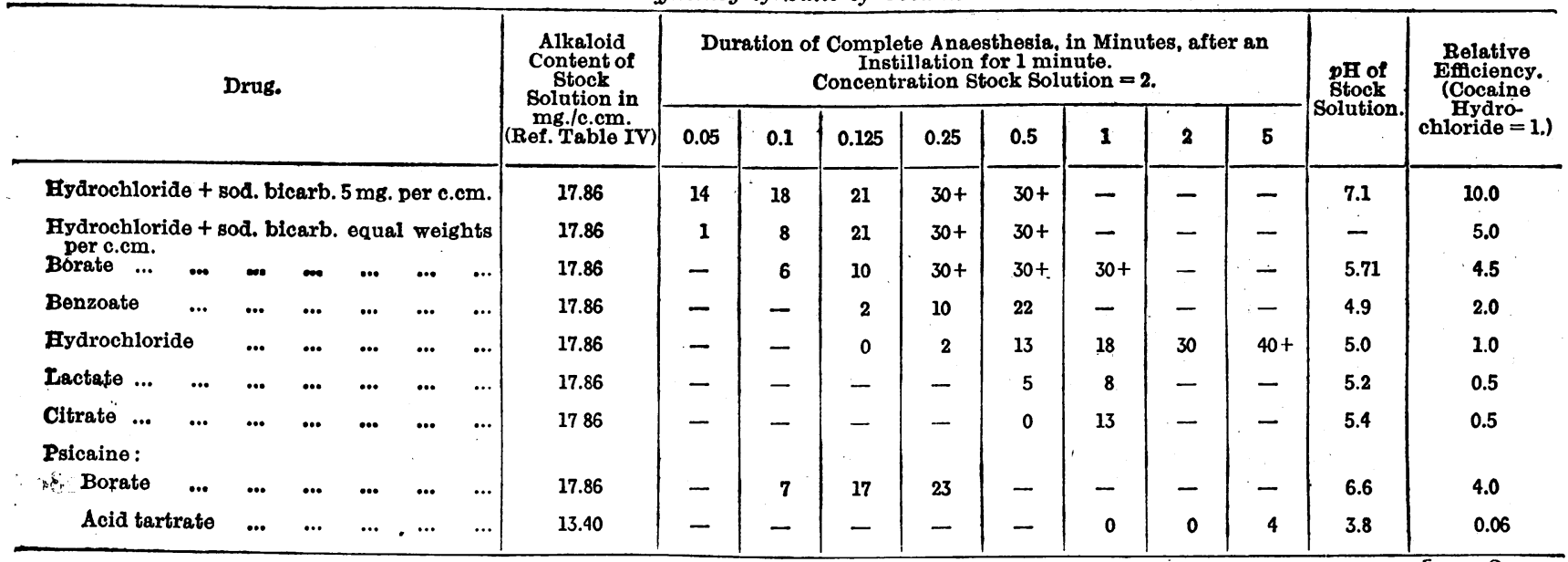


Table II.-Anaesthetic Efficiency of Salts of Cocaine Substitutes on Rabbit's Cornea.

\begin{tabular}{|c|c|c|c|c|c|c|c|c|c|c|c|c|c|c|c|}
\hline \multirow{2}{*}{\multicolumn{4}{|c|}{ Druss. }} & \multirow{2}{*}{$\begin{array}{l}\text { Alkaloid } \\
\text { Content } \\
\text { of Stock } \\
\text { Solution } \\
\text { in } \\
\text { mg./e.cm. }\end{array}$} & \multirow{2}{*}{$\begin{array}{l}\text { Percentage } \\
\text { of Solid } \\
\text { Salt in } \\
\text { Stock } \\
\text { Solution. }\end{array}$} & \multicolumn{8}{|c|}{$\begin{array}{c}\text { Duration of Complete Anaesthesia, in Minutes, after an } \\
\text { Instillation for } 1 \text { minute. } \\
\text { Concentration Stock Solution }=2 .\end{array}$} & \multirow{2}{*}{$\begin{array}{c}\text { pH of } \\
\text { Stock } \\
\text { Solution. }\end{array}$} & \multirow{2}{*}{$\begin{array}{c}\text { Relative } \\
\text { Effeiency. } \\
\text { (Cocaine } \\
\text { Hydro- } \\
\text { chloride }=1 . \text { ) }\end{array}$} \\
\hline & & & & & & 0.05 & 0.1 & 0.125 & 0.25 & 0.5 & 1 & 2 & 5 & & \\
\hline $\begin{array}{c}\text { I. EccaINe G } \\
\text { Beta-eucaine: } \\
\text { Borate... } \\
\text { Jactate }\end{array}$ & $\begin{array}{l}\text { inotP } \\
\ldots \\
\ldots\end{array}$ & $\ldots$ & $\ldots$ & $\begin{array}{l}14 . F 6 \\
14.66\end{array}$ & $\begin{array}{l}2.75 \\
2.0\end{array}$ & 19 & $30+$ & $30+$ & ${ }_{0}^{30+}$ & $\overline{0}$ & $\begin{array}{l}30+* \\
10\end{array}$ & $\overline{16}$ & $\overline{23}$ & 8.0 & $\begin{array}{r}20.0 \\
0.5\end{array}$ \\
\hline $\begin{array}{l}\text { II. HolocaINe } \\
\text { Holocaine: } \\
\text { Borate... } \\
\text { Hydrochloride }\end{array}$ & $\begin{array}{l}\text { Grot } \\
\ldots \\
\ldots\end{array}$ & $\ldots$ & $\begin{array}{l}\ldots \\
\ldots\end{array}$ & $\begin{array}{l}17.82 \\
17.82\end{array}$ & $\begin{array}{l}3.09 \\
2.0\end{array}$ & $=$ & 13 & $\begin{array}{r}35 \\
6\end{array}$ & $\begin{array}{l}40+ \\
14\end{array}$ & $\overline{19}$ & $\overline{31}$ & $\overline{50}$ & $=$ & $\begin{array}{l}6.2 \\
6.1\end{array}$ & $\begin{array}{l}9.0 \\
2.5\end{array}$ \\
\hline $\begin{array}{l}\text { III. ЕтносаINe } \\
\text { "G.S.": } \\
\text { Borate... } \\
\text { Hydrochloride }\end{array}$ & $\begin{array}{l}\text { Groo } \\
\cdots \\
\cdots\end{array}$ & $\ldots$ & $\ldots$ & $\begin{array}{l}17.50 \\
17.50\end{array}$ & $\begin{array}{l}3.09 \\
2.0\end{array}$ & 8 & 22 & 40 & $\stackrel{40+}{1}$ & $\overline{4}$ & $\overline{22}$ & $\overline{32}$ & $=$ & $\begin{array}{l}6.4 \\
5.2\end{array}$ & $\begin{array}{r}10.0 \\
1.0\end{array}$ \\
\hline $\begin{array}{l}\text { Butyn: } \\
\quad \text { Borate } \ldots \\
\quad \text { Sulphate } \\
\quad \cdots\end{array}$ & $\ldots$ & $\ldots$ & $\begin{array}{l}\ldots \\
\cdots \\
\end{array}$ & $\begin{array}{l}17.20 \\
17.20\end{array}$ & $\begin{array}{l}2.93 \\
2.0\end{array}$ & $\underline{6}$ & $\begin{array}{r}23 \\
0\end{array}$ & $\overline{4}$ & $\overline{11}$ & $\overline{16}$ & $\overline{30}$ & $\overline{42}$ & $\overline{45}+$ & $\begin{array}{l}6.4 \\
5.6\end{array}$ & $\begin{array}{r}10.0 \\
2.0\end{array}$ \\
\hline $\begin{array}{l}\text { Stovaino: } \\
\quad \text { Porate... } \\
\quad \text { Hydrochloride }\end{array}$ & $\ldots$ & $\ldots$ & $\begin{array}{l}\ldots \\
\cdots\end{array}$ & $\begin{array}{l}17.32 \\
17.32\end{array}$ & $\begin{array}{l}3.34 \\
2.0\end{array}$ & $=$ & $\underline{5}$ & 10 & $=$ & $=$ & * & $\begin{array}{c}* \\
12\end{array}$ & $\overline{18}+$ & $=$ & $\begin{array}{l}4.0 \\
0.25\end{array}$ \\
\hline $\begin{array}{l}\text { Tutocain: } \\
\text { Borate... } \quad \ldots \\
\text { Borate.... } \\
\text { Hydrochloride }\end{array}$ & $\begin{array}{l}\ldots \\
\ldots \\
\ldots\end{array}$ & $\begin{array}{l}\ldots \\
\ldots \\
\ldots\end{array}$ & $\cdots$ & $\begin{array}{l}17.45 \\
10.63 \\
17.45\end{array}$ & $\begin{array}{l}3.28 \\
2.0 \\
2.0\end{array}$ & $\bar{z}$ & $\underline{6}$ & $\begin{array}{r}17 \\
3 \\
-\end{array}$ & $\begin{array}{l}30+ \\
-18\end{array}$ & $\begin{array}{c}30+ \\
30+ \\
0\end{array}$ & $\overline{\frac{1}{6}}$ & $\overline{\overline{16}}$ & $\overline{\overline{21}}$ & $\frac{7.2}{5.8}$ & $\begin{array}{l}4.0 \\
2.0 \\
0.5\end{array}$ \\
\hline $\begin{array}{l}\text { Alypine: } \\
\quad \text { Borate...... } \\
\quad \text { Hydrochloride }\end{array}$ & $\begin{array}{l}\ldots \\
\ldots\end{array}$ & $\ldots$ & $\begin{array}{l}\ldots \\
\ldots\end{array}$ & $\begin{array}{l}17.68 \\
17.68\end{array}$ & $\begin{array}{l}3.16 \\
2.0\end{array}$ & $\underline{0}$ & $\stackrel{0}{-}$ & 10 & $\begin{array}{r}18 \\
0\end{array}$ & $\overline{2}$ & $\begin{array}{l}1 \\
10\end{array}$ & $\overline{22}$ & $\overline{34}$ & 8.12 & $\begin{array}{l}4.0 \\
0.7\end{array}$ \\
\hline $\begin{array}{l}\text { Ethocaine : } \\
\quad \text { Borrate... } \\
\text { Borate.... } \\
\text { Hydrochloride }+ \\
\quad 10 \text { mg. per c.cm }\end{array}$ & $\begin{array}{l}\ldots \\
\ldots \\
\text { sod. }\end{array}$ & $\begin{array}{l}\ldots \\
\dddot{b i c a}\end{array}$ & $\begin{array}{r}\ldots \\
\ldots \ldots \\
x\end{array}$ & $\begin{array}{l}17.40 \\
10.53 \\
17.40\end{array}$ & $\begin{array}{l}3.27 \\
2.0 \\
-\end{array}$ & $\bar{z}$ & $\underline{0}$ & $\begin{array}{l}2 \\
0 \\
-\end{array}$ & $\begin{array}{r}14 \\
5 \\
3\end{array}$ & $\begin{array}{r}23 \\
15 \\
8\end{array}$ & $\begin{array}{l}30+ \\
25 \\
18\end{array}$ & $\overline{30}$ & $=$ & $\begin{array}{l}8.2 \\
8.2 \\
8.4\end{array}$ & $\begin{array}{l}2.5 \\
1.0 \\
1.0\end{array}$ \\
\hline $\begin{array}{l}\text { Bicarbonate... } \\
\text { Phosphate }\end{array}$ & $\ldots$ & $\ldots$ & $\ldots$ & 17.40 & - & - & - & - & - & 4 & 12 & 30 & - & - & 0.5 \\
\hline $\begin{array}{ll}\text { Phosphate } & \ldots \\
\text { Phosphate } & \ldots .\end{array}$ & $\ldots$ & $\ldots$ & $\ldots$ & $\begin{array}{l}17.40 \\
17.40\end{array}$ & $=$ & $=$ & $\bar{z}+$ & $\underline{0}$ & $\begin{array}{l}0 \\
0\end{array}$ & 11 & 23 & $\overline{38}$ & $=$ & 8.2 & 1.0 \\
\hline $\begin{array}{l}\text { Phosphate } \ldots \\
\text { Benzoate }\end{array}$ & $\ldots$ & $\ldots$ & $\ldots$ & 17.40 & $=$ & $\overline{-}$ & $=$ & $=$ & 0 & 0 & 0 & 0 & $\bar{z}+$ & $\begin{array}{l}7.0 \\
5.8\end{array}$ & \\
\hline $\begin{array}{ll}\text { Benzoate } & \ldots \\
\text { Balicylate } & \ldots\end{array}$ & $\ldots$ & $\ldots$ & $\ldots$ & $\begin{array}{l}17.40 \\
17.40\end{array}$ & $=$ & $\bar{z}$ & $=$ & $=$ & $\underline{0}$ & 2 & 10 & 15 & $=$ & 4.4 & 0.5 \\
\hline Lactate & $\ldots$ & & $\ldots$ & 17.40 & - & - & - & - & - & - & 0 & 9 & $30+$ & $\overline{5.4}$ & $\begin{array}{l}0.25 \\
0.25\end{array}$ \\
\hline $\begin{array}{l}\text { Hydrochloride } \\
\text { Acid tartrate }\end{array}$ & $\ldots$ & $\ldots$ & $\ldots$ & $\begin{array}{l}17.40 \\
17.40\end{array}$ & $=$ & $\bar{z}$ & $\overline{-}$ & $\bar{z}$ & $\bar{z}$ & $=$ & $\underline{0}$ & $\begin{array}{l}0 \\
0\end{array}$ & 2 & $\begin{array}{l}5.6 \\
3.8\end{array}$ & 0.05 \\
\hline $\begin{array}{l}\text { "523": } \\
\text { Borate... } \\
\text { Hydrochloriäe }\end{array}$ & $\ldots$ & $\ldots$ & $\begin{array}{l}\ldots \\
\ldots\end{array}$ & $\begin{array}{l}17.55 \\
17.55\end{array}$ & $\overline{2.0}$ & $=$ & $\overline{-}$ & $\frac{2}{-}$ & 6 & $30+$ & $\overline{0}$ & $\overline{5}$ & $\bar{z}$ & $\begin{array}{l}6.4 \\
5.2\end{array}$ & $\begin{array}{l}2.0 \\
0.125\end{array}$ \\
\hline $\begin{array}{l}\text { IV. MIXTu } \\
\text { Feta-eucaine borate } \\
\text { borate } 4\end{array}$ & RE. & thoca & & - & - & - & - & - & 22 & - & - & - & - & - & 4.0 \\
\hline
\end{tabular}

Signifies marked irritatıon.

+ Signifies irritation.

This conclusion is of interest in the case of cocaine, but it becomes of predominant importance when applied to the cases of cocaine substitutes which, though powerfully anaesthetic when administered subcutaneously, have little or no surface anaesthetic effect. Most of the cocaine substitutes are used in the form of the hydrochloride, in which the electrolytic dissociation predominates, and little is known concerning surface anaesthesia which might be provoked by the hydrolytically dissociated salts. A series of salts of ethocaine (novocain) base were therefore prepared, and their surface anaesthetic action compared in aqueous solutions of equivalent concentration in base; the results are included in Table II. Although ethocaine hydrochloride exerts an almost negligible surface anaesthetic action, that action becomes practically as marked as that of a cocaine hydrochloride solution of equivalent strength when the solution is made alkaline by addition of sodium bicarbonate. An indication is thus obtained that, while the electropositive ethocaine ion exercises but little surface anaesthetic action, the free base existing in the hydrolytically dissociated form has the same surface anaesthetic value as cocaine hydrochloride.

The equilibrium conditions as between electrolytic and hydrolytic dissociation which hold in solutions of ethocaine hydrochloride to which sodium bicarbonate has been added are complex, and cannot be immediately defined; further, such solutions tend to deposit the free base. Salts of ethocaine base were therefore prepared in which feeble acids were associated with the base; in the aqueous solutions of these the $p \mathbf{H}$ values are high, and hydrolytic dissociation thus predominates. Ethocaine borate, which is on the alkaline side of neutrality in that its $p \mathbf{H}$ value is greater than 7.0, and in which the hydrolytic dissociation thus tends to the maximum, is seen from the table to be a more powerful surface anaesthetic than cocaine hydrochloride of similar equivalent concentration. The results tabulated for other salts of the ethocaine base are in general support of the conclusion that the surface anaesthetic effect is increased as the hydrolytic dissociation increases and the electrolytic dissociation diminishes. The whole of the observations now recorded lead to the general conclusion that surface anaesthetic action is determined by the base in the free dissolved state, and not by the electrolytically ionized base.

For the purpose of further testing the general applica. bility of this conclusion to surface anaesthetics as a class, comparative experiments were made with a number of local anaestheties in the form in which they are usually employed-namely, as hydrochloride or sulphate-and in the form of the borates, these latter salts being prepared from the commercially available salt. Reference to Table II shows that in every case the borate has a much greater surface anaesthetic action than the electrolytically highly dissociated salt in general use. In the course of this work the solid crystalline borates of cocaine, ethocaine, butyn, tutocain, holocaine, alypine, stovaine, and beta-eucaine were prepared, together with the borates of two new ethocaine derivatives from the Abbott laboratories labelled "G.S." and " 523 ": "G.S." is the hydrochloride of beta- $n$-butylallylamino- $p$-aminobenzoate, and " 523 " the hydrochloride of isopropylallylamino-p-aminobenzoylethanol. 
have received practically no attention from chemists; scarcely any of these substances have hitherto been prepared in a state of purity. This is naturally due to the fact that they undergo hydrolytic dissociation in aqueous solution, and thus in general could not be obtained pure by crystallization from water. Einhorn and Uhlfelder, ${ }^{5}$ the discoverers of ethocaine, did indeed describe a crystalline borate of this base, and assigned to it the composition $\mathrm{C}_{13} \mathrm{H}_{20} \mathrm{O}_{2} \mathrm{~N}_{2}, 4 \mathrm{~B}\left(\mathrm{OH}_{3}\right)$, but we have not been able to prepare a stable compound of this formula. A definite ethocaine borate may be obtained by crystallizing the ethocaine base with the corresponding amount of boric acid from acetone solution; this compound retains its composition unchanged on crystallization from organic solvents such as acetone, alcohol, and the like.

The composition of this and the other new borates which we have analysed is given in Table III; it will be noted that they are of the type of the inorganic pentaborates described by Atterberg. ${ }^{18}$

The borates are conveniently prepared by mixing solutions of the base and of boric acid in either hot or cold acetone, the proportions being those indicated by the composition of the salt; the pure borate crystallizes out on standing. Alternatively boric acid and excess of the base may be dissolved in acetone and the solution evaporated to dryness; after powdering the residue and extracting the excess of base with ether it yields the pure borate on recrystallization from a water-free organic solvent. The details of the preparation naturally differ slightly in the cases of the different bases, but, in general, the borates are obtained by crystallizing the base with boric acid from an organic solvent in absence of water.

Of the borates examined those of ethocaine, betaeucaine, and alypine alone give stable solutions in water; solutions of the others, in consequence of the hydrolytic dissociation, deposit the free base more or less rapidly on standing. This can be obviated by the addition of a further small proportion of boric acid; such addition, however, depresses the $p \mathrm{H}$ value and simultaneously leards to a diminution of the surface anaesthetic effect. The three which are stable in aqueous solution seem to be indicated for general use.

Psicaine (the acid tartrate of $d$ - $\psi$-cocaine) has been shown ${ }^{13}$ to have an anaesthetic action on the cornea which is considerably weaker than its low base content suggests; it is as toxic as cocaine hydrochloride. The borate is more than fifty times as powerful as psicaine of equal base strength on the cornea, but it is not more efficient than cocaine borate. This isomer of cocaine, then, has no advantage over cocaine, and it is unnecessary to pursue the subject.

It will be seen (Table II) that the cocaine substitutes are divided for convenience into three groups. In the novocain group, to which new members are constantly being added, it is found that the borates of "G.S." and butyn are the most powerful; these substances may be of some value in ocular anaesthesia, but are unlikely to be of value for other purposes owing to their toxicity, to uncertainty in action due to their precipitation by saline and by tissue fluids, and to the instability of the borates. "G.S." is a hydrochloride ; it is approximately as efficient as cocaine hydrochloride on the rabbit's cornea; the minimum lethal dose for rabbits by subcutaneous injection of 5 per cent. solution is about $160 \mathrm{mg}$. per kilogram, the minimum lethal dose of cocaine hydrochloride being about $75 \mathrm{mg}$. per kilogram. ${ }^{13}$

Tutocain ${ }^{12}{ }^{19}$ is less efficient for anaesthesia of the cornea and less toxic than cocaine hydrochloride. The borate of the base has approximately the anaesthetic efficiency of cocaine borate on the cornea, but it is unstable.

Ethocaine in many respects is the ideal surface anaesthetic, because its less dissociated salts are practically without toxicity and cause no irritation. The borate is approximately as efficient as cocaine hydrochloride on the rabbit's cornea. It causes slight vascular congestion, and has no effect on the pupil. It does not produce anaesthesia in such low concentrations as do the borates of "G.S.," butyn, and holocaine, but its advantages in low toxicity, lack of irritation, and stability make this of little moment, since it is at a great advantage when dose, toxicity, irritation, and anaesthetic efficiency are all taken into account. The solution keeps well, and does not precipitate in contact with the tissues.

The following experiments on two rabbits of approximately equal weight indicate its low toxicity:

Rabbit A, $1.05 \mathrm{~kg}$., received a subcutaneous injection of $2.5 \mathrm{c.cm}$. of a 5 per cent. solution of ethocaine hydrochloride (dose $=120 \mathrm{mg}$. per kg.). Ten minutes after injection tonic spasms occurred, with retraction of the head and rigidity of limbs lasting thirty-five minutes, followed by severe clonic spasms lasting some minutes. This was followed by some paralysis lasting eighty minutes after injection, after which the rabbit recovered.

Rabbit B, $1.10 \mathrm{~kg}$., received injection of $2.6 \mathrm{c.cm}$. of 5 per cent. et hocaine borate (dose $=120 \mathrm{mg}$. per kg.). As a result fifteen minutes after injection the rabbit became quiet for two minutes, after which it was normal. No convulsion or paralysis or other after which it was normal.
sign of toxicity was observed.

The minimum lethal dose of ethocaine borate by subcutaneous injection in rabbits was not determined, since for a rabbit weighing $1.65 \mathrm{~kg}$. even the cnormous doso of 20 c.cm. of a 5 per cent. solution of the borate 1 gram or $600 \mathrm{mg}$. per kg.) was not lethal. The animal was partly paralysed for one hour and the bronchial secretions were increased, but there were no symptoms suggesting stimulation of the cortex (for example, head retraction, twitchings of facial muscles, convulsions), and the corneal reflex was never lost. Complete recovery occurred two hours after injection. These experiments show that the toxicity of ethocaine borate is negligible. The borate, like the hydrochloride, is non-irritant, and $0.5 \mathrm{c.cm}$. of a 20 per cent. solution injected subcutaneously into a rabbit's shaved abdominal wall caused only faint bruising on the second day, and thereafter no signs of irritation.

TABLE III.-Composition of Borates.

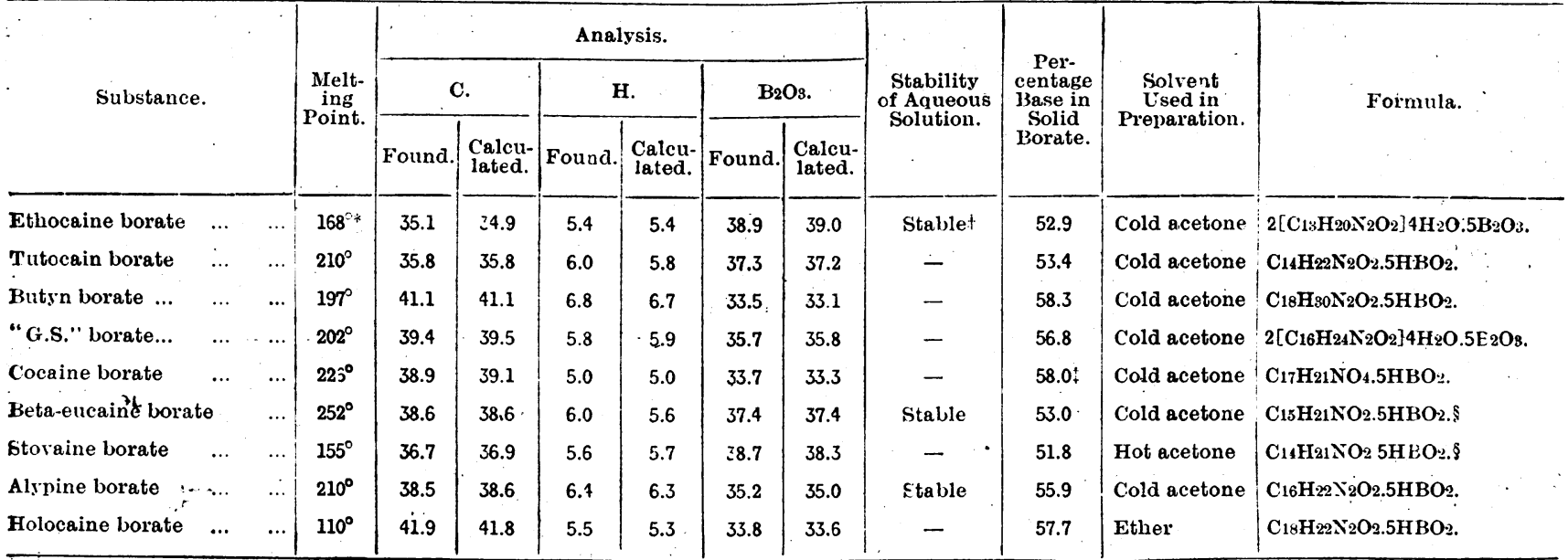

* Einhorn and Uhlfelder (loc. cit.) give $159^{\circ}-160^{\circ}$. t The word "stable" indicates that the solution in water does not require the addition of boric acid to prevent separation of base. 1 A. B. Iyons (loc. cit.) gives 55 par cent. which is lost on heating in vacuo at $90^{\circ} \mathrm{C}$. Analyses refer to the dried substance 
In the nose of the cat, using the perfusion method, ${ }^{12}$ ethocaine borate causes congestion of the erectile tissue of the nose, as shown by obstruction to the flow. This is, however, less decided than after butyn, "G.S.," or cocaine borate, and stimulation of the sympathetics immediately corrected this-that is to say, the vasomotor nerves are not paralysed. After the use of the other substitutes stimulation of the sympathetics is usually without effect. In other words, ethocaine borate can be given with adrenaline and so cause all the desired anaesthesia together with shrinkage of the tissuex.

Cocaine hydrochloride acts equally well both for surface and hypodermic use. Ethocaine hydrochloride, on the other hand, only acts hypodermically; as a surface anaesthetic it is useless; did it act as a surface anaesthetic the necessity for cocaine would be gone. On the other hand, all the borates, like cocaine hydrochloride, act both as surface and hypodermic anaesthetics. It has been shown that this is not entirely due to the $p \mathrm{H}$; and the table shows that the different borocaines exert different degrees of surface anaesthesia which cannot altogether be explained by the stability of the different salts, so that a third factor-that of specific affinity for nerve tissues-requires consideration. This factor does not show the wide differences between the different cocaine substitutes that might, a priori, be expected; most of the bases are good anaesthetics. Moreover, such comparisons are open to many objections. We have, however, endeavoured to obtain somo approximate figures by dissolving the hases in castor oil and determining tho effect on the eye. Such observations show that holocaine, tutocain, and cocaine bases have much the same degree of action. Ethocaine has about onc-half the specific effect of cocaine, while other substances such as apothesine produce marked irritation before anaesthesia.

The other salts of ethocaine are shown in Table II for the purpose of comparing $\mathrm{H}$-ion concentration of solution with anaesthetic efficiency. An example of this may be mentioned in further detail.

Expcrimcnt.-10 c.cm. of 2 per cent. ethocaine phosphate $(p \mathrm{H} 7.0)$ was rendered slightly alkaline by the addition of $0.15 \mathrm{c.cm}$. of $\mathrm{N} / 5 \mathrm{NaOH}$, the $p \mathrm{H}$ being raised to 8.4. The result of this was to double the anaesthetic efficiency so that it equalled that of cocaine hydrochloride.

$10 \mathrm{c.cm}$. of the solution was rendered slightly acid by the addition of 0.04 c.cm. of 21 per cent. phosphoric acid, the $p \mathbf{H}$ being thereby powered to 5.6. The result of this was to diminish the anaesthesia to less than one-tenth that of cocaine hydrochloride $(p H 5.0)$ and to equal that of novocain hydrochloride ( $p \mathrm{H} 5.6)$.

The soluticn $(p \mathrm{H} 5.6)$ was now rondered slightly alkaline, the $p$ H being raised from 5.6 to 8.4 , with the result that the efficiency was raised to that of cocaine hydrochloride (see Table II).

The borate of " 523 " base has twice the efficiency of cocaine hydrochloride on the cornea, but its toxicity has not been determined.

Holocaine hydrochloride is much employed in eye work, especially in the United States. ${ }^{10}$ The borate is extremely powerful, possessing an anaesthetic efficiency on the cornea which is greater than eight times that of cocaine hydrochloride, though less than that of the borates of "G.S." and butyn bases. Holocaine has the advantage over "G.S." and butyn in not being precipitated by saline or tissue fluids; the borate may be useful for ocular anaesthesia.

The borate of beta-eucaine base is the most powerful borocaine, being more than ten times as efficient as cocaine hydrochloride. The toxicity is not yet determined.

Table IV deals with a derivative of quirine, which Dixon has shown paralyses nerve endings and has little or no affinity for nerve fibrils. Isoamylhydrocupreine bi-hydrochloride is said to produce anaesthesia of the rabbit's cornea in strengths of 0.09 per cent.- that is, it should be more than four times as powerful as cocaine hydrochloride. Our experiments do not confirm this, but they show that such quinine derivatives are highly irritant. The borate of this alkaloid was prepared and was found to have about sixty times the anaesthetic power of cocaine hydrochloride. Here, then, is an alkaloid exerting its action in a manner entirely different from that of cocaine and its substitutes, and yet the same principle obtains, the electrolytically less dissociated salts being much more active than the hydrochloride.

It may be well here to state the properties of one borate clearly; for this purpose we select that most generally useful
TABLE IV.-Anacsthetic Efficiency of Salts of a Quinine Derivative on Rabbit's Cornea.

\begin{tabular}{|c|c|c|c|c|c|c|c|}
\hline \multirow[t]{2}{*}{ Drugs. } & \multirow{2}{*}{$\begin{array}{l}\text { Alkaloid } \\
\text { Content of } \\
\text { Stock } \\
\text { Solution in } \\
\text { mg./c.cm. }\end{array}$} & \multicolumn{4}{|c|}{$\begin{array}{c}\text { Duration of Complete } \\
\text { Anaesthesia in Minntes. } \\
\text { Concentration Stock } \\
\text { Solution }=0.5 .\end{array}$} & \multirow{2}{*}{$\begin{array}{c}p \text { H } \\
\text { of } \\
\text { Stock } \\
\text { Solu- } \\
\text { tion. }\end{array}$} & \multirow{2}{*}{$\begin{array}{c}\text { Relative } \\
\text { Efficiency } \\
\text { (Cocaine } \\
\text { Hydro- } \\
\text { chloride } \\
=1 . \text { ) }\end{array}$} \\
\hline & & 0.03 & 0.04 & 0.05 & 0.1 & & \\
\hline \multicolumn{8}{|l|}{$\begin{array}{l}\text { Isoamylhydro- } \\
\text { cupreine: }\end{array}$} \\
\hline $\begin{array}{ccc}\text { Borate } \quad \ldots & \ldots\end{array}$ & 4.2 & 0 & $30+$ & $30+$ & $30+*$ & 6.4 & 60 \\
\hline Bihydrochloride & 4.2 & 0 & 0 & $0^{*}$ & $0^{*}$ & 4.0 & $?$ \\
\hline
\end{tabular}

* Signifies marked irritation.

-ethocaine borate. This substance is stable and freely soluble in cold water and Ringer's solution. It does not precipitate proteins like the borates of butyn and "G.S."The specific gravity of a 5 per cent. solution is high (1.0139), which is useful for spinal anaesthesia. It is non-irritant. It causes anaesthesia of the human eye in 2 per cent. solutions, the onset being very rapid, and it is equally effective in the urethra and probably other surfaces. Its toxicity is negligible. By subcutaneous injection it is as effective as ethocaine hydrochloride and adrenaline, but not more so. The objection to its use is that it dilates vessels, but this effect can be largely overcome by using adrenaline. In the nose it causes decided congestion; whether this effect can be overcome by adrenaline is for clinical observers to decide.

The borates of the local anaesthetic bases possess, as has been shown in the present paper, entirely specific properties as surface anaesthetics, and it may be convenient to class them together under the name of "borocaines." The efficiency of the borocaines as surface anaesthetics depends upon the $p \mathrm{H}$ value for the salt in aqueous solution being kept high-namely, on the alkaline sido of neutrality; great care has therefore to be taken in preparing the salt to ensure that no factor is introduced which will depress the $p \mathrm{H}$ value. For this reason the manufacture of the borocaines has been entrusted to The British Drug Houses, Ltd., and this firm is prepared to supply the compounds.

\section{Conclusions.}

1. The action of a local anaesthetic depends upon the specific selective affinity of its base for nerve fibrils. But the different salts of such a base vary greatly according to the acid with which they are combined. If they are combined with strong acids (that is, those which dissociate electrolytically to a large extent), the salt is relatively rapidly absorbed into the general circulation and is less effective locally-that is, its toxicity is relatively high and its anaesthetic action relatively low. On the other hand, if it is combined with a weak acid which does not electrolytically dissociate to any considerable extent, it is relatively slowly absorbed into the general circulation and is more effective locally-that is, its toxicity is relatively low and its specific anaesthetic efficiency relatively high. Such salts have a high $p \mathbf{H}$ value.

2. A new group of local anaesthetics, the borocaines, is described, the members of which fulfil these conditionsthat is, they are much less toxic than the original hydrochlorides, from which they can be prepared, but often exert more than ten times the anaesthetic action.

Clinical reports will follow.

We desire to express thanks to the Medical Research Council for the special grant it made for the expenses of this research.

We also desire to thank Professor Sir William Pope for his advice and assistance on the chemical side, and Professor W. E. Dixon for help and advice throughout the investigation.

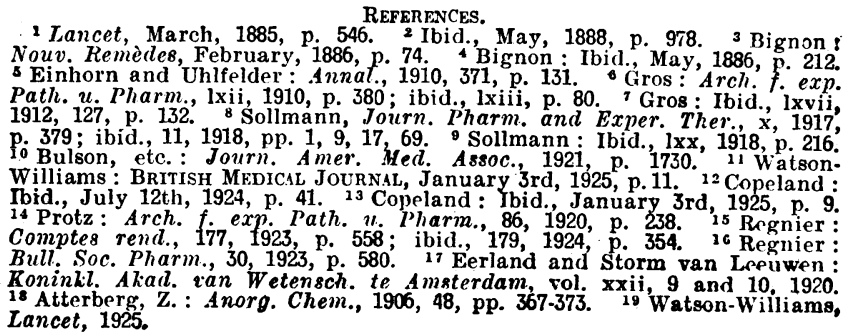

